NBER WORKING PAPER SERIES

\title{
EFFECTS OF EMPLOYMENT PROTECTION ON WORKER AND JOB FLOWS: EVIDENCE FROM THE 1990 ITALIAN REFORM
}

\author{
Adriana Kugler \\ Giovanni Pica \\ Working Paper 11658 \\ http://www.nber.org/papers/w11658
NATIONAL BUREAU OF ECONOMIC RESEARCH
1050 Massachusetts Avenue
Cambridge, MA 02138
September 2005

We are grateful to Joshua Angrist, Giuseppe Bertola, Antonio Ciccone, Steve Pischke and especially Andrea Ichino for useful suggestions. We thank Bruno Contini of the LABORatorio Riccardo Revelli for kindly providing us with the INPS data set and Federico Cingano and Alfonso Rosolia for additional data. Adriana Kugler thanks the Spanish Ministry of Science and Technology through Grant No. SEC-2001-0674 for financial support.E-mails: adkugler@uh.edu and g.pica@ soton.ac.uk. The views expressed herein are those of the author(s) and do not necessarily reflect the views of the National Bureau of Economic Research.

(O2005 by Adriana Kugler and Giovanni Pica. All rights reserved. Short sections of text, not to exceed two paragraphs, may be quoted without explicit permission provided that full credit, including $\odot$ notice, is given to the source. 
Effects of Employment Protection on Worker and Job Flows: Evidence from the 1990 Italian Reform

Adriana Kugler and Giovanni Pica

NBER Working Paper No. 11658

September 2005

JEL No. E24, J63, J65

\title{
$\underline{\text { ABSTRACT }}$
}

This paper uses the Italian Social Security employer-employee panel to study the effects of the Italian reform of 1990 on worker and job flows. We exploit the fact that this reform increased unjust dismissal costs for firms below 15 employees, while leaving dismissal costs unchanged for bigger firms, to set up a natural experiment research design. We find that the increase in dismissal costs decreased accessions and separations for workers in small relative to big firms, especially in sectors with higher employment volatility. Moreover, we find that the reform reduced firms' employment adjustments on the internal margin as well as entry rates while increasing exit rates.

\author{
Adriana D. Kugler \\ University of Houston \\ Department of Economics \\ 204 McElhinney Hall \\ Houston, TX 77204-5019 \\ and NBER \\ adkugler@uh.edu \\ Giovanni Pica \\ Department of Economics \\ University of Salerno \\ Via Ponte don Melillo \\ 84084 Fisciano \\ ITALY \\ g.pica@soton.ac.uk
}




\section{Introduction}

Theory makes clear-cut predictions on the effects of employment protection on labour reallocation (see, e.g., Bertola (1990) and Hopenhayn and Rogerson (1993)). While a number of cross-country studies examine the impact of dismissal costs on aggregate and sectoral employment adjustments, there are few empirical studies on the impact of dismissal costs on worker and job flows using individual and firm level data. Moreover, studies using micro-data often focus on the internal margin of adjustment, and often ignore adjustments on the external margin through entry and exit.

In this paper, we use an Italian employer-employee panel to examine the effect of dismissal costs on worker and job flows. Italy is an interesting country to study this issue because it is one of the strictest countries in terms of employment protection legislation. More importantly, in 1990 Italy introduced a labour market reform which increased employment protection for workers employed under permanent contracts in firms with less than 15 employees relative to those in firms with more than 15 employees. We exploit the differential increase in the costs of unfair dismissals in small relative to large firms after 1990 to study the impact of dismissal costs on labour flows. We use a differences-in-differences approach by comparing worker and job flows in small and large firms before and after the reform.

Our empirical analysis uses administrative data from the Italian Social Security Institute (INPS). Our data set is an employer-employee panel, which includes information on: dates of appointment and separation of the worker; dates of incorporation and termination of the firm, and the yearly average number of employees. We use these data to examine worker flows (i.e., accessions and separations), and job flows on the internal and external margin (i.e., employment changes and entry and exit). We find that accessions and separations decreased after the reform by about 10\% for both men and women in small relative to large firms, and the results are robust to the inclusion of sector and region effects, sector-specific trends, sectoral productivity, and size-specific cyclical effects. Moreover, we find evidence of a bigger effect of the reform in previously more volatile sectors.

Consistent with smaller worker flows after the reform, we also find employment changes fell by about $15 \%$ in small relative to big firms after the reform. Moreover, we examine the impact of dismissal costs on firms' external margins of adjustment. In particular, we find that small firms are less likely to enter the market after the reform compared to large firms. By contrast, small firms are more likely to exit the market after the reform compared to large firms, which is consistent with firms' attempts to circumvent the legislation given that closing firms are not responsible for unjust dismissal payments. Moreover, as for worker flows, we find that these effects tend to be larger in more volatile sectors.

A number of previous studies have exploited the variation across firms in 
employment protection legislation within Italy $\prod^{1}$ Boeri and Jimeno (2003) assess the effect of employment protection on lay-off probabilities by comparing small and large firms, though they do not exploit the temporal change in the legislation. Borgarello, Garibaldi and Pacelli (2002), and Schivardi and Torrini (2004) evaluate the effects of employment protection on the size distribution of Italian firms, by looking at the probability of adjustments in size for firms around the fifteen employee threshold. These three papers identify the effect of employment protection by exploiting the fact that, in Italy, firms with less than 15 employees are subject to lower dismissal costs than firms with more than 15 employees. This amounts to capturing the effect of interest by comparing the performance of small and large firms. Borgarello, Garibaldi and Pacelli (2002) also present some results exploiting the temporal variation in employment protection, but their sole focus is on the effect of employment protection on firm size and they do not control for size-specific cyclical effects in their analysis ${ }^{2}$

The rest of the paper is organized as follows. Section 2 describes the evolution of dismissal costs in Italy. Section 3 explains the identification strategy used to evaluate the impact of dismissal costs in Italy. Section 4 describes the Social Security data and presents estimates of the effects of the rise in dismissal costs on worker and job flows in Italy.

\section{Employment Protection Regulations in Italy}

Italy, together with the other Southern European countries, is considered one of the strictest countries in terms of employment protection legislation (EPL). For example, a study by Lazear (1990) for the period 1956-84 and a study by Bertola (1990) for the late 1980s rank Italy as the strictest country in terms of EPL. A study by the OECD's Employment Outlook for the late 1980s, ranks Portugal as the strictest country followed by Italy, Spain, and Greece. A similar study by the OECD's Employment Outlook for the late 1990s, which includes Turkey, North America, and transition economies as well, continues to rank Portugal as the strictest, followed by Turkey, Greece, Italy and Spain. The study by Nicoletti et al. (2000), which does not include some of the countries in the OECD's Employment Outlook study, also ranks Italy third, after Portugal and the Netherlands, in terms of the strictness of regulations on permanent contracts.

Dismissals were first regulated in Italy in 1966 through Law No. 604, which established that, in case of unfair dismissal, employers had the choice to either hire back workers or pay a dismissal cost, which depended on tenure and firm

\footnotetext{
${ }^{1}$ Ichino and Riphahn (2004) exploits the within firm variation.

${ }^{2}$ Other studies exploiting within-country variation to examine the effect of dismissal costs on labour reallocation include: Kugler (1999); Hunt (2000); Oyer and Schaeffer (2000); Acemoglu and Angrist (2001); Kugler, Jimeno and Hernanz (2003); Autor (2003); Autor, Donohue III and Schwab (2004), Kugler and Saint-Paul (2004), Kugler and Pica (2004); and Friesen (2005).
} 
size. Payments for unfair dismissals ranged between 5 and 8 months for workers with less than two and a half years of tenure; between 5 and 12 months for those between two and a half and 20 years of tenure; and between 5 and 14 months for workers with more than 20 years of tenure in firms with more than 60 employees ${ }^{3}$ Firms with less than 60 employees had to pay half the amount paid by firms with more than 60 employees, and firms with less than 35 workers were completely exempt.

In 1970, the Statuto dei Lavoratori (Law No. 300) established that all firms with more than 15 employees had to hire back workers and pay their foregone wages in case of unfair dismissals. Firms with less than 15 employees, however, remained exempt ${ }^{4}$ A number of recent studies show evidence of the binding effect of this law for firms at the 15 employee threshold. For example, the last annual report by the Italian Statistical Office, ISTAT, shows a larger fraction transiting to a smaller size category for firms around the 15 employee threshold than for firms at any other sizes. Similarly, Garibaldi, Pacelli and Borgarello (2003) and Schivardi and Torrini (2004) find a (slightly) higher probability of inaction and a higher probability of reducing firm size than of increasing it for firms at the 15 employee threshold.

Given the high costs of unfair dismissals for larger firms, in 1987 the Italian government liberalized the use of temporary contracts in an attempt to provide more flexibility to employers. Prior to 1987, temporary contracts could be used for specific projects, seasonal work, or for replacement of temporarily absent permanent workers. After 1987, temporary contracts could be used more widely subject to collective agreements specifying certain target groups. While the extended use of temporary contracts allowed for more flexibility in the labour market, these contracts could only be renewed up to two times and could only have a maximum length of 15 months. Consequently, even though temporary contracts were liberalized after this reform, the use of temporary contracts remained heavily regulated in Italy compared to other countries ${ }^{5}$

Soon after the 1987 reform, Law No. 108 was introduced in 1990 further restricting dismissals for permanent contracts. In particular, this law introduced costs for unfair dismissals of between 2.5 and 6 months pay for unfair dismissals in firms with less than 15 employees. By contrast, unfair dismissal costs in firms with more than 15 employees remained as before. This meant that, after 1990, the

\footnotetext{
${ }^{3}$ By contrast, payments for fair dismissals entail no cost to employers, as they are paid from workers' retained earnings.

${ }^{4}$ Boeri and Jimeno (2003) present a theoretical explanation of why these exemptions may be in place to begin with. They argue that exempting small firms reduces the disemployment effect of dismissal costs because, in their model, smaller firms subject to dismissal costs have to pay much higher efficiency wages to discourage shirking than larger firms.

${ }^{5}$ Note that, according to the OECD's Employment Outlook (1999), Italy ranked first in terms of strictness of the regulation of fixed-term contracts during the 1980s and it continued to rank first during the 1990 s.
} 
cost of unfair dismissals for firms with less than 15 employees increased relative to the costs for firms with more than 15 employees ${ }^{6}$ By contrast, in 1997, Italy moved again in the direction of trying to provide firms with a margin of flexibility by legalizing the use of temporary help agencies. While the 1990 reform increased the costs of unfair dismissals for permanent contracts in firms with less than 15 employees relative to firms with more than 15 employees, the 1987 and 1997 reforms introduced flexibility at the margin by deregulating the use of temporary contracts and temporary lay-offs. Since our data is for the period of 1986 to 1995, in this paper we exploit the temporal change in dismissal costs generated by the 1990 reform for permanent workers, which applied differently for small and large firms 7

\section{Identification Strategy}

The goal of this paper is to identify the impact of dismissal costs on worker and job flows. In order to do so, we compare the change in the performance of firms with less than 15 employees before and after the 1990 reform to the change in the performance of firms with more than 15 employees. Since firm size may be affected by the reform itself, we define small firms as having less than 15 employees in all years before the reform and large firms as having more than 15 employees in all years before the reform 8

The strategy to identify the impact of the change in dismissal costs is illustrated in Figures 1 4 . Figures 1 and 2 show accession and separation probabilities in firms with less than 15 employees and firms with more than 15 employees for the period 1986 to 1995. Figure 1 shows a sharper decline in accession probabilities in small firms than in large firms, starting from 1991, i.e. right after the 1990 reform. Figure 2 shows a somewhat more pronounced decline in the separation

\footnotetext{
${ }^{6}$ In 1991, the Italian government also introduced other reforms. First, the government introduced fiscal incentives by reducing payroll taxes (i.e., social security contributions) for firms with more than 15 employees. However, as shown in Kugler, Jimeno, and Hernanz (2003), while an increase in dismissal costs should reduce both hiring and dismissals, a reduction in payroll taxes should increase hiring but have no effect on dismissals. Also, in 1991, the government introduced a special procedure legislation allowing for collective dismissals (i.e. dismissals of more than 5 employees within a range of 110 days) in firms with more than 15 employees. We include in our sample only firms below 35 employees, who are less likely to be hit by a shock large enough to cause lay-offs of (more than) 5 employees. Finally, in 1992, the government eliminated a wage indexation mechanism (Scala Mobile), which had been adopted in 1945, for firms of all sizes.

${ }^{7}$ Since we focus on permanent workers in our empirical analysis, we are unlikely to capture the effect of the 1987 reform. Moreover, we also tried limiting the sample to the period from 1987 to 1995 to eliminate any possible effect of the liberalization of temporary contracts in 1987 and our results are the same.

${ }^{8}$ We thus eliminate from the sample firms whose size crosses the 15 employee threshold before the reform, so that we can focus on firms whose size is already at some "steady state".
} 
probabilities in small relative to big firms starting in 1989, which suggests firms may have anticipated the reform. Figure 3 shows a greater decrease in entry for small relative to large firms after 1990, while figure 4 shows a larger increase in exit rates for small than large firms at least until 1993.

\subsection{Worker Flows: Accessions and Separations}

To control for the possibility that reduced accessions and separations are the result of changing characteristics of workers and firms in different size categories, we estimate the following linear probability model:

$$
E\left[m_{i j t}=1 \mid X_{i j t}, S_{j}, D_{j}^{S}, \text { Post }_{t}\right]=\beta^{\prime} X_{i j t}+\delta_{0} \text { Post }_{t}+\delta_{1} S_{j}+\delta_{2} D_{j}^{S}+\delta_{3}\left(D_{j}^{S} \times \text { Post }_{t}\right)
$$

where the dependent variable $m_{i j t}$ is a dummy variable that takes the value of 1 if a match was created or destroyed, i.e., if there was either an accession or a separation, between worker $i$ and firm $j$ at time $t$. The matrix $X_{i j t}$ includes: firm characteristics, such as sector and region, and worker characteristics such as age, occupation and gender. Post $t_{t}$ is a dummy that takes the value of 1 after 1990 and zero otherwise. $S_{j}$ is the yearly average firm size, and $D_{j}^{S}$ is a dummy that takes the value of 1 if the worker is employed in a small firm and 0 if the worker is employed in a large firm. The interaction term between the small firm dummy and the post-reform dummy captures the effect of interest.

Comparing the periods before and after would control for the possibility that changes in job reallocation in small relative to large firms after the post-reform period were due to macro shocks, if small and large firms were affected similarly by macro shocks. It is possible, however, that the business cycle affects small and large firms differently. If this were the case, then we should have observed both reduced accessions and increased separations during the post-reform period due to the strong recession of 1992 and 1993. Instead, Figures 1 and 2 above show both reduced accessions and separations. Nonetheless, to make sure we control for differential cyclical effects on firms of different sizes, we also estimate the following alternative specification:

$$
\begin{aligned}
E\left[m_{i j t}=1 \mid X_{i j t}, S_{j}, D_{j}^{S}, \text { Post }_{t}, E_{t}\right]= & \beta^{\prime} X_{i j t}+\phi_{0} E_{t}+\phi_{1}\left(D_{j}^{S} \times E_{t}\right)+ \\
& +\delta_{0} \text { Post }_{t}+\delta_{1} S_{j}+\delta_{2} D_{j}^{S}+ \\
& +\delta_{3}\left(D_{j}^{S} \times \text { Post }_{t}\right)
\end{aligned}
$$

where $E_{t}$ is an expansion variable which is either a dummy taking the value of 1 during the recession years of 1992 and 1993 or the growth rate of GDP. The size-specific cyclical effect is captured away by the interaction term between the small firm dummy $D_{j}^{S}$ and the variable $E_{t}$.

The introduction of dismissal costs should have a stronger effect on more volatile sectors, where these costs are likely to bind. To check whether the rise in 
dismissal costs after the reform had a greater effect in small firms in more volatile sectors, we estimate the following linear probability model:

$$
\begin{aligned}
E\left[m_{i j t}=1 \mid X_{i j t}, S_{j}, D_{j}^{S}, \text { Post }_{t}, V_{k}\right]= & \beta^{\prime} X_{i j t}+\delta_{0} \text { Post }_{t}+\delta_{1} S_{j}+\delta_{2} D_{j}^{S}+ \\
& +\delta_{3}\left(D_{j}^{S} \times \text { Post }_{t}\right)+\gamma_{0} V_{k}^{S}+ \\
& +\gamma_{1}\left(V_{k}^{S} \times D_{j}^{S}\right)+\gamma_{2}\left(V_{k}^{S} \times \text { Post }_{t}\right) \\
& +\gamma_{3}\left(V_{k}^{S} \times D_{j}^{S} \times \text { Post }_{t}\right)
\end{aligned}
$$

where $V_{k}$ denotes the sectoral variance of employment growth during the prereform period. The coefficient $\gamma_{3}$ captures the differential effect of dismissal costs on sectors with different degrees of volatility.

\subsection{Firms' Employment Changes, Entry and Exit}

To confirm that the reductions in accessions and separations were due to the reform and not simply to the fact that workers are churning more during the 1990s for reasons unrelated to the reforms, we examine whether changes in permanent employment fell in small relative to large firms, even after controlling for firm effects. In particular, we estimate the following linear probability model:

$$
\begin{aligned}
E\left[\left|\Delta L_{j t}\right| \mid Z_{j t}, S_{j}, D_{j}^{S}, \text { Post }_{t}\right]= & \theta^{\prime} Z_{j t}+\psi_{j}+\rho_{0} \text { Post }_{t}+\rho_{1} S_{j}+\rho_{2} D_{j}^{S}+ \\
& +\rho_{3}\left(D_{j}^{S} \times \text { Post }_{t}\right)
\end{aligned}
$$

where $Z_{j t}$ is a vector which includes sector and region effects, and sectoral productivity in some specifications. Post $_{t}, S_{j}, D_{j}^{S}$ are, as before, the post-reform dummy, the yearly average firm size and the small firm dummy. Finally, $\psi_{j}$ is a firm effect, where the regression is estimated with and without the firm effect.

While the above regression captures the effect of dismissal costs on the internal margin of adjustment, we are also interested on the effects on the external margins. In particular, we estimate the effects of the 1990 reform on firms' entry and exit rates. We use the longitudinal information on firms to estimate the following linear probability model:

$$
\begin{aligned}
E\left[e_{j t}=1 \mid W_{j t}, S_{j}, D_{j}^{S}, \text { Post }_{t}\right]= & \lambda W_{j t}+\psi_{j}+\pi_{0} \text { Post }_{t}+\pi_{1} S_{j}+\pi_{2} D_{j}^{S}+ \\
& +\pi_{3}\left(D_{j}^{S} \times \text { Post }_{t}\right)
\end{aligned}
$$

where the dependent variable $e_{j t}$ is a dummy variable that takes the value of 1 if firm $j$ enters or exits the market at time $t$. The vector $W_{j t}$ includes sector and region effects. Post $_{t}, S_{j}, D_{j}^{S}$ are as described above. As for the regression of employment changes, we estimate this linear probability model with and without firm effects. Moreover, we extend the above specifications to control for sizespecific cyclical effects (as in equation (2p) and to allow for differential effects on sectors with different volatility (as in equation (3p). 


\section{Effects of Dismissal Costs}

\subsection{Data Description}

The data set is drawn from the Italian Social Security Administration (INPS) archives for the years 1986-1995. The original data set collects social security forms of a 1/90 random sample of employees every year, with workers born on the 10th of March, June, September, and December of every year being sampled. The original archives only include information on private sector firms in the manufacturing and service sectors, so that it excludes all workers in the public sector and agriculture. We use a 10\% random sample from this original data set.

The data set includes individual longitudinal records generated using social security numbers. However, since the INPS collects information on private sector employees for the purpose of computing retirement benefits, employees are only followed through their employment spells. The data does not follow individuals who move into self-employment, the public sector, the agricultural sector, the underground economy, unemployment, or retirement. The data set also includes longitudinal records for firms employing the randomly selected workers in the sample using the firms' name, address, and social security and fiscal codes. While the data set includes a random sample of workers, the probability that a firm is selected increases with size. When using the panel of firms, we account for this by weighting each observation by the probability that it appears in the sample, which is given by the average number of employees divided by 90 .

The data set is, thus, an employer-employee panel with information on workers and firm characteristics. In particular, the data includes information on employees' age, gender, occupation, dates of accession and separation with each firm, and type of contract, and information on firms' location, sector of employment, number of employees, and firms' dates of incorporation and termination. The advantage of this administrative data for the purpose of studying the effects of dismissal costs on worker transitions and firms' entry and exit probabilities is that, contrary to survey data which measures transitions by matching quarterly data and using tenure information to identify job changes, in our data we can identify the exact dates of accessions and separations according to when social security contributions began and ended. Moreover, the exact dates of incorporation and termination of the employing firm are recorded in the INPS archives.

Tables 1 and 2 present descriptive statistics for men and women separately by firm size, before and after the 1990 reform. Men's accessions and separations decrease after 1990 in both small and large firms, but more in small firms. Similarly, women's accessions and separations fall more in small than in large firms, though the effect on separations is stronger. These simple comparisons of means suggest that the Italian 1990 reform appears to have reduced accessions and separations of both men and women.

Table 3 presents descriptive statistics on firms' characteristics. In particular, 
this table shows that entry rates fell in small and large firms after the reform, though the fall was more pronounced in small firms. On the other hand, exit rates increased similarly both in small and large firms after the reform. Finally, the volatility of employment (measured as the variance of employment) fell in small firms, while it increased for large firms, after the reform. Though these simple comparisons of means suggest that the increase in dismissal costs as a result of the reform may have slowed down employment adjustments, some of these changes could be due to changes in sectoral composition or location of small firms. The following sections present results which control for covariates.

\subsection{Effects on Accessions}

Table 4 reports marginal effects of a linear probability model for accessions estimated using equations (1)-(3). The dependent variable is a variable that takes the value of 1 if the person joined a firm in a given year and zero otherwise. These linear probability models are estimated using a sample of permanent workers and of firms with less than 35 employees. The sample is restricted to firms with less than 35 employees to increase comparability between the treatment group of firms with less than 15 employees and the control group of firms with more than 15-employees.9

Panels $\mathrm{A}$ and $\mathrm{B}$ in Table 4 report results for men and women, including controls for worker's age and occupation, firm's sector and location, firm size and year effects, as well as sector productivity, sector-specific trends and size-specific cyclical effects. The reported standard errors allow for clustering by period-size group to control for common random effects within these cells. Overall, the results show a large and statistically significant decline in permanent accessions in small relative to large firms after the 1990 reform was introduced. Column (1) shows that accession probabilities decreased by 0.019 or $8.2 \%$ for men and by 0.02 or $9.2 \%$ for women in small relative to big firms during the reform years. Including sector-specific trends and sector productivity in Columns (2) and (3) leaves the effects on accession probabilities basically unchanged. Moreover, controlling for size-specific cyclical effects in Columns (4) and (5) reduces the effect for men to -0.01 , while increasing the effect for women to -0.02610

Columns (6) reports results which include the third-level interaction of the post-reform dummy, the small firm dummy and the volatility of employment

\footnotetext{
${ }^{9}$ Results are robust to changes in the 35 employees threshold.

${ }^{10}$ In some specifications we tried including worker effects. The effects are similar but less precise. This is not surprising given that we loose many workers from the sample because workers are not followed once moving out of the labour force, or to the underground economy. At the same time, given that accessions and separations are moving in the same direction, it is unlikely that changes in workers' unobservable characteristics after 1990 are behind these patterns. For example, if less-employable individuals look for work in small firms during the 1990s, this could explain the decrease in accessions in small firms after 1990, but it could not explain the decrease in separations.
} 
growth, as described in equation (3) 11 The results in this table show that the probability of an accession falls drastically for workers employed in small firms after the reform if they are employed in a highly volatile sector, where dismissal costs are likely to bind. For example, accessions fall by $17 \%$ for men and by $38 \%$ for women in small relative to large firms in sectors where the variance of employment is three standard deviations above the mean, but only by $6 \%$ for men and $15 \%$ for women in sectors where the variance of employment is two standard deviations above the mean. This confirms that workers employed in firms where dismissal costs are likely to bind appear to be most affected the 1990 reform. This is reassuring since it confirms that we are probably capturing the effect of the reform, rather than the effect of some other contemporaneous shock or legislative change that should not be affect differently sectors with different volatilities.

\subsection{Effects on Separations}

Table 5 reports marginal effects of linear probability models for separations. The dependent variable is now a variable that takes the value of 1 if the person separated from the firm in a given year and zero otherwise. The controls in these specifications are as in the linear probability models for accessions.

As before, Panel A of Table 5 reports the results for men and Panel B for women. The results show that separation probabilities decreased for both men and women. For example, the results from the basic specification show a decrease in separation probabilities of 0.029 or $9 \%$ for men and of 0.034 or $10.4 \%$ for women. Controlling for sector-specific trends and sector productivity makes the effects for men slightly larger, but does not affect the results for women. Results controlling for size-specific cyclical effects suggest that the effect of the reform is even larger. In particular, separation probabilities now fall by $9.6 \%$ for men and by $14.4 \%$ for women.

Results of specifications including the third-level interaction between the postreform dummy, the small firm dummy and the pre-reform volatility of employment growth are reported in Column (6). We do not find a differential fall in separations for men in highly volatile sectors. By contrast, the results for women show that separations fall a lot more for women in small relative to large firms in highly volatile sectors. For example, separations fall by $48 \%$ for women in small relative to large firms in sectors where the employment variance is three standard deviations above the mean, but only by $20 \%$ for women in sectors where the employment variance is two standard deviations above the mean 12

\footnotetext{
${ }^{11}$ Also in this case, we have ran different specifications (controlling for size-specific cyclical effects, sectoral productivity and individuals effects) that we do not report for brevity, as the results do not change.

${ }^{12}$ Again, adding controls for size-specific cyclical effects, sectoral productivity and individuals effects does not change the picture offered by column (6).
} 


\subsection{Effects on Employment Changes}

We then analyse whether the increase in dismissal costs decreased employment adjustments in the internal and external margins in small relative to large firms. While the data set includes a random sample of workers, the probability that a firm is selected increases with size. We account for this by weighting each observation by the probability that the firm actually appears in the sample, which is given by average number of employees divided by 9013

To look at the effects of dismissal costs on the internal margin, we regress the absolute value of firms' employment growth on the interaction between the postreform dummy and the small firm dummy, controlling for a number of covariates including firm fixed effects. Table 6 reports results of specifications controlling for different covariates. All specifications show that the 1990 reform reduced employment changes in small relative to large firms. The size of the reduction seems large as the lowest estimates, which control for size-specific cyclical effects and firm effects, implies a drop of $15 \%$ in the willingness to adjust employment ${ }^{14}$

\subsection{Effects on Entry and Exit}

To look at the effects on the external margins, we estimate linear probability models of entry and exit. Table 7 reports results from estimating equation (5). The dependent variable is a dummy variable that takes the value of 1 if the firm entered (Panel A) or exited (Panel B) the market. As for employment changes, we weight each observation by the probability that the firm appears in the sample and adjust standard errors to allow for clustering by period-size group.

Panel A shows that the entry rate of small firms goes down relative to large firms after the 1990 reform. This result is robust to the inclusion of sector productivity, sector-specific trends, size-specific cyclical effects, and firm effects, and the results range between a $10 \%$ and a $24 \%$ reduction. Moreover, the results in Columns (7) and (8), which include a third level interaction with the variance of employment, show that the reduction in entry rates is larger the greater the employment volatility. For example, an increase in employment volatility of two standard deviations decreases entry by as much as 30\%, and an increase of three standard deviations decreases entry by as much as $70 \%$.

By contrast, Panel B shows that the exit rate of small firms increases relative to large firms after the 1990 reform, where the results range between $18 \%$ and $50 \%$. As for entry, the results are robust to the inclusion of sector trends, sector

\footnotetext{
${ }^{13}$ As for accessions and separations, only firms with no more than 35 workers are included and the effect of interest is captured by the interaction between the post-reform dummy and a dummy for firms under 15 employees. Also in this case, the reported standard errors allow for clustering by period-size group to control for common random effects within these cells.

${ }^{14}$ The results do not change if the error term is assumed to follow auto-regressive processes of order one or two.
} 
productivity, size-specific cyclical effects, and firm effects. This is consistent with the theory (see, e.g., Hopenhayn and Rogerson, 1993), as a rise in dismissal costs lowers the present value of the future stream of profits, thus, leading to greater exit. Moreover, given that closing firms are not subject to costs for unjust dismissals, small firms subject to sufficiently large shocks may close up the firm and re-open in order to by-pass the regulation. In addition, we find that the effect is stronger for firms in more volatile sectors. Columns (7) and (8) show that the increase in the exit rates is larger the larger the employment volatility, though the effect becomes less precise when firm effects are included.

\section{Conclusion}

In this paper, we present new evidence on the impact of dismissal costs on worker and job flows. We use an employer-employee panel from the Italian Social Security to examine the effects of dismissal costs on workers' accessions and separations, and on firms' employment changes as well as entry and exit. We exploit the fact that dismissal costs increased in Italy after the 1990 reform for firms with less than 15 employees relative to larger firms. This reform allows to adopt a differences-in-differences approach that arguably helps to overcome identification problems in some of the studies that use cross-country variation and cross-sectoral variation in dismissal costs within a country.

We find that both accession and separation probabilities decreased for men and women in small relative to large firms after the reforms. In particular, our results imply a decrease of as much as $10 \%$ in accessions and separations. Moreover, we find that the effect is more pronounced in those sectors that were more volatile before the reform, and where dismissal costs are likely to bind.

Aside from the effect of the reform on worker flows, we also find that the reform affected employment adjustments on the internal and external margins. On the internal margin, we find that the reform reduced employment adjustments by as much as $15 \%$. On the external margin, our lower bound estimates suggest that the rise in dismissal costs reduced entry by about $10 \%$ while increasing exits by about $18 \%$. In addition, as for worker flows, we find that these effects appear to be stronger in sectors whose pre-reform employment volatility was larger and where dismissal costs are more likely to bind.

Overall, these results support the view that dismissal costs lower mobility by reducing employment adjustments and flows into and out of employment. At the same time, we have examined the impact of dismissal costs on the external margin of adjustment, which has hardly been looked at in previous studies, and find that while dismissal costs reduce entry, they also reduce firm survival. 


\section{References}

[1] Acemoglu, Daron and Joshua Angrist. 2001. "Consequences of Employment Protection? The Case of the American with Disabilities Act," Journal of Political Economy, 109(5): 915-957.

[2] Autor, David. 2003. "Outsourcing at Will: The Contribution of Unjust Dismissal Doctrine to the Growth of Employment Outsourcing," Journal of labour Economics, 21(1): 1-42.

[3] Autor, David, John J. Donohue III and Stewart J. Schwab. 2002. "The Costs of Wrongful Discharge Laws," NBER Working Paper No. 9425.

[4] Bertola, Giuseppe. 1990. "Job Security, Employment, and Wages", European Economic Review, 54(4): 851-79.

[5] Boeri, Tito and Juan F. Jimeno. 2003. "The Effects of Employment Protection: Learning from Variable Enforcement", CEPR Discussion Paper No.3926.

[6] Borgarello, Andrea, Pietro Garibaldi and Lia Pacelli. 2004. "Employment Protection Legislation and the Size of Firms," Il Giornale degli Economisti, N. 1.

[7] Contini, Bruno. 2002. Osservatorio sulla mobilità del lavoro in Italia. Bologna: Il Mulino.

[8] Friesen, Jane. 2005. "Statutory firing costs and lay-offs in Canada", Labour Economics, 12(2): 147-168.

[9] Hopenhayn, Hugo and Richard Rogerson.1993. "Job Turnover and Policy Evaluations: A General Equilibrium Analysis", Journal of Political Economy, 101: 915-38.

[10] Hunt, Jennifer. 2000. "Firing Costs, Employment Fluctuations, and Average Employment: An Examination of Germany", Economica, 67(266):177-202.

[11] Ichino Andrea and Regina T. Riphahn. 2004. "The Effect of Employment Protection Legislation on Worker Effort. A Comparison of Absenteeism During and After Probation", Journal of the European Economic Association, forthcoming

[12] ISTAT. 2002. Annual Report. Rome: ISTAT Publications.

[13] Kugler, Adriana.1999. "The Impact of Firing Costs on Turnover and Unemployment: Evidence from the Colombian Labour Market Reform", International Tax and Public Finance, 6(3): 389-410. 
[14] Kugler, Adriana, Juan F. Jimeno and Virginia Hernanz. 2003. "Employment Consequences of Restrictive Permanent Contracts: Evidence from Spanish labour Market Reforms", CEPR Working Paper No. 3724.

[15] Kugler, Adriana, and Giovanni Pica. 2004. "The Effects of Employment Protection and Product Market Regulations on the Italian Labor Market", forthcoming in Julian Messina, Claudio Michelacci, Jarkko Turunen, and Gylfi Zoega, Eds., Labour Market Adjustments in Europe. Edward Elgar

[16] Kugler, Adriana and Gilles Saint-Paul. 2004. "How do Firing Costs affect Worker Flows in a World with Adverse Selection?", Journal of Labor Economics, 22(3): 553-584.

[17] Lazear, Edward. 1990. "Job Security Provisions and Employment”, Quarterly Journal of Economics, 105(3): 699-726.

[18] Nicoletti, Giuseppe, Stefano Scarpetta and Olivier Boylaud, (2000), Summary Indicators of Product Market Regulation with an Extension to Employment Protection Legislation, OECD WP 226

[19] OECD. 1999. Employment Outlook. Paris: OECD

[20] Oyer, Paul and Scott Schaeffer. 2000. "Layoffs and Litigation," RAND Journal of Economics, 31(2): 345-358.

[21] Schivardi, Fabiano, and Roberto Torrini. 2004. "Firm Size Distribution And Employment Protection Legislation In Italy," Tema di discussione della Banca d'Italia, No. 504. 


\section{A Figures and Tables}

Figure 1: Yearly accession probabilities conditional on firm size (below/above 15 employees

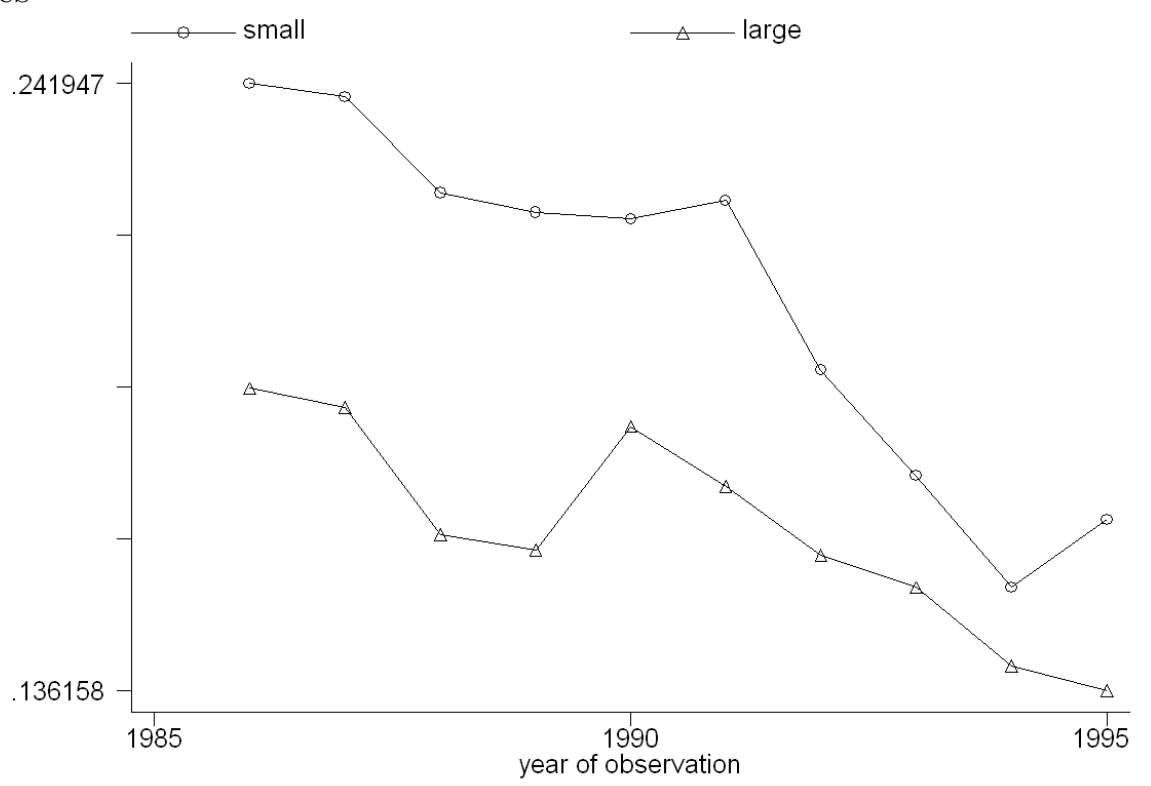

Figure 2: Yearly separation probabilities conditional on firm size (below/above 15 employees)

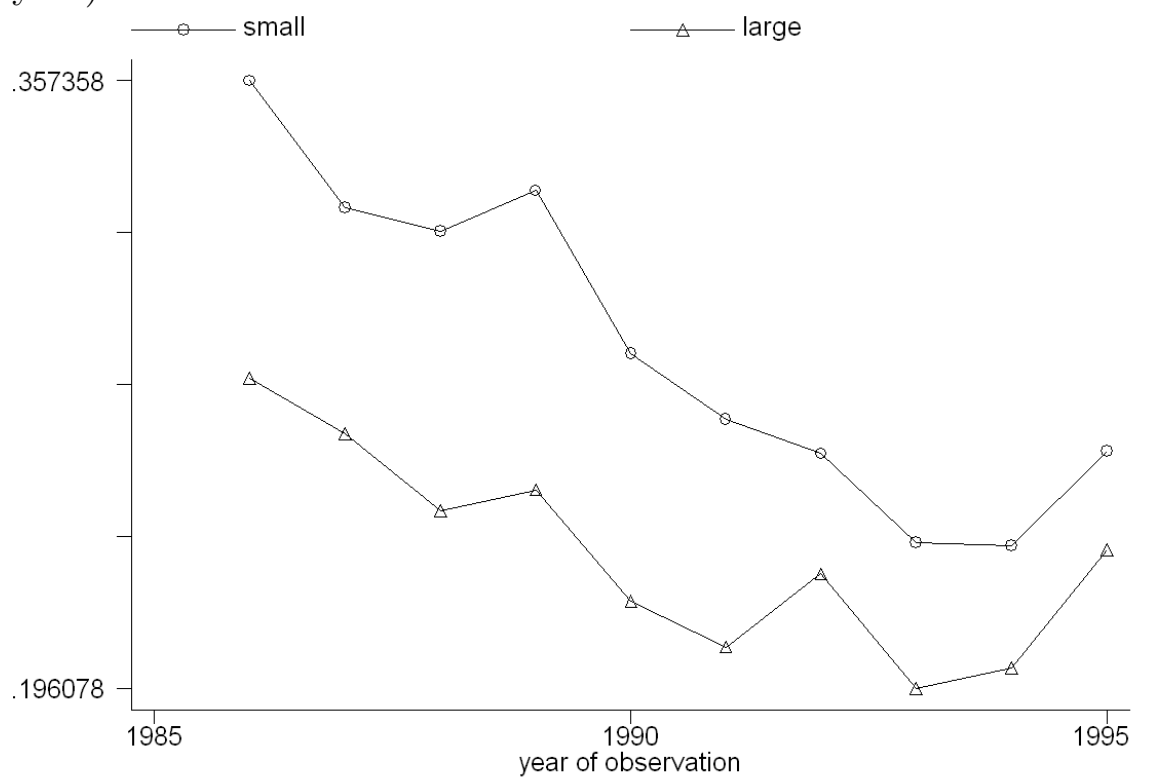


Figure 3: Yearly entry probabilities conditional on firm size (below/above 15 employees)

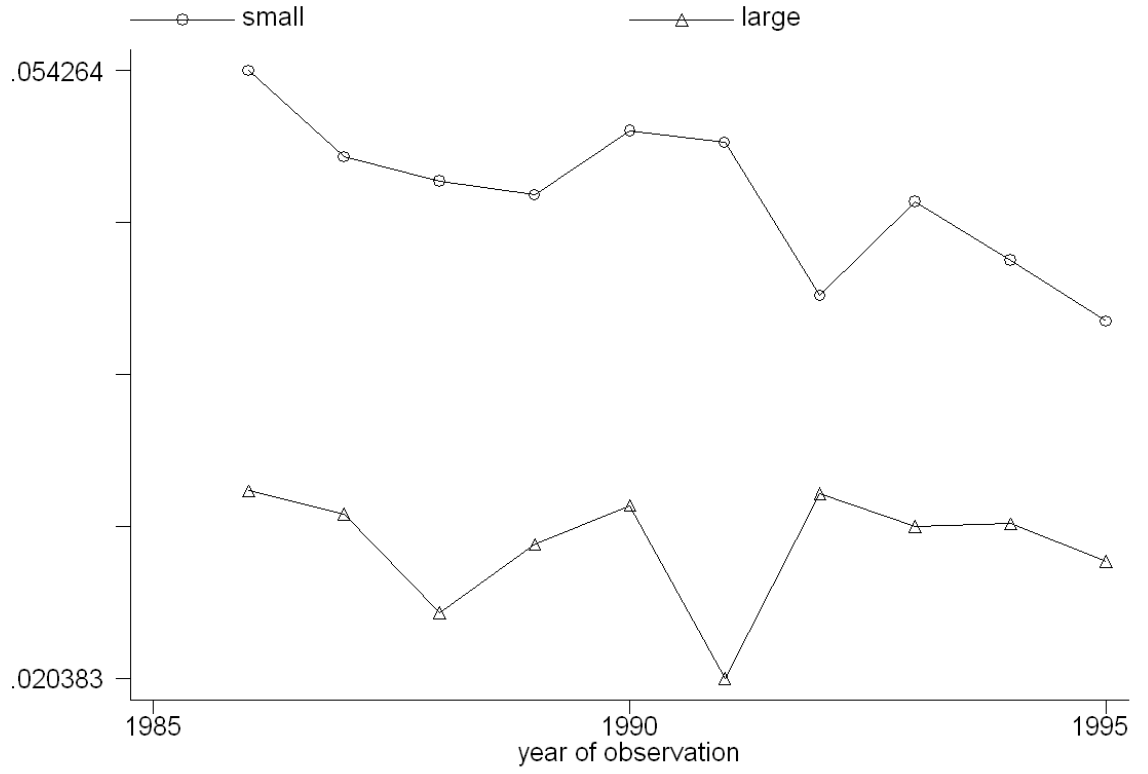

Figure 4: Yearly exit probabilities conditional on firm size (below/above 15 employees)

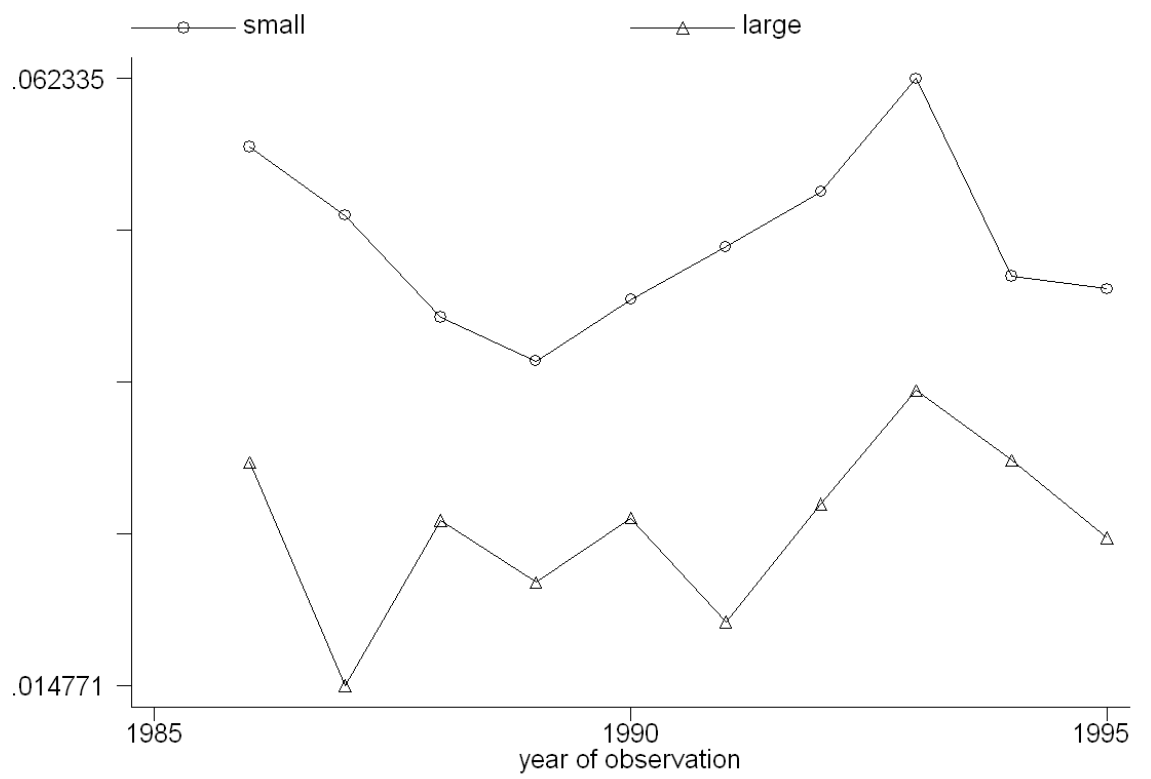


Table 1: Men. Descriptive statistics by firm size, before and after the reform

\begin{tabular}{|c|c|c|c|c|}
\hline \multirow[t]{2}{*}{$\overline{\text { Variables }}$} & Pre-reform & Post-reform & Pre-reform & Post-reform \\
\hline & \multicolumn{2}{|c|}{ Small firms } & \multicolumn{2}{|c|}{ Large firms } \\
\hline Age & $\begin{array}{c}35.79 \\
(11.32)\end{array}$ & $\begin{array}{c}36.99 \\
(10.75)\end{array}$ & $\begin{array}{c}37.39 \\
(11.24)\end{array}$ & $\begin{array}{c}38.35 \\
(10.54)\end{array}$ \\
\hline$\%$ of blue collars & $\begin{array}{l}0.81 \\
(0.4)\end{array}$ & $\begin{array}{c}0.81 \\
(0.39)\end{array}$ & $\begin{array}{c}0.76 \\
(0.43)\end{array}$ & $\begin{array}{c}0.74 \\
(0.44)\end{array}$ \\
\hline Yearly average size of the firm & $\begin{array}{c}6.48 \\
(3.98)\end{array}$ & $\begin{array}{c}6.9 \\
(4.16)\end{array}$ & $\begin{array}{l}24.81 \\
(5.72)\end{array}$ & $\begin{array}{c}24.28 \\
(5.9)\end{array}$ \\
\hline Accession rate & $\begin{array}{c}0.23 \\
(0.42)\end{array}$ & $\begin{array}{c}0.19 \\
(0.39)\end{array}$ & $\begin{array}{c}0.17 \\
(0.38)\end{array}$ & $\begin{array}{c}0.16 \\
(0.36)\end{array}$ \\
\hline Separation rate & $\begin{array}{c}0.32 \\
(0.47)\end{array}$ & $\begin{array}{c}0.26 \\
(0.44)\end{array}$ & $\begin{array}{c}0.24 \\
(0.43)\end{array}$ & $\begin{array}{c}0.21 \\
(0.41)\end{array}$ \\
\hline$N$ & 12321 & 12640 & 4822 & 5931 \\
\hline
\end{tabular}

Notes: Only permanent workers and firms below 35 workers are included. The pre-reform period goes from 1986 to 1990, the post-reform period from 1991 to 1995. Standard deviations in parenthesis.

Table 2: Women. Descriptive statistics by firm size, before and after the reform

\begin{tabular}{|c|c|c|c|c|}
\hline \multirow[t]{2}{*}{$\overline{\text { Variables }}$} & Pre-reform & Post-reform & Pre-reform & Post-reform \\
\hline & \multicolumn{2}{|c|}{ Small firms } & \multicolumn{2}{|c|}{ Large firms } \\
\hline Age & $\begin{array}{l}32.18 \\
(9.72)\end{array}$ & $\begin{array}{c}34.05 \\
(9.4)\end{array}$ & $\begin{array}{l}32.44 \\
(9.42)\end{array}$ & $\begin{array}{c}34.18 \\
(9.1)\end{array}$ \\
\hline$\%$ of blue collars & $\begin{array}{c}0.42 \\
(0.49)\end{array}$ & $\begin{array}{c}0.43 \\
(0.49)\end{array}$ & $\begin{array}{l}0.53 \\
(0.5)\end{array}$ & $\begin{array}{l}0.55 \\
(0.5)\end{array}$ \\
\hline Yearly average size of the firm & $\begin{array}{c}6.32 \\
(3.98)\end{array}$ & $\begin{array}{c}6.58 \\
(4.16)\end{array}$ & $\begin{array}{l}24.75 \\
(5.75)\end{array}$ & $\begin{array}{c}23.75 \\
(5.8)\end{array}$ \\
\hline Accession rate & $\begin{array}{c}0.22 \\
(0.42)\end{array}$ & $\begin{array}{c}0.17 \\
(0.37)\end{array}$ & $\begin{array}{c}0.18 \\
(0.38)\end{array}$ & $\begin{array}{c}0.14 \\
(0.35)\end{array}$ \\
\hline Separation rate & $\begin{array}{c}0.32 \\
(0.47)\end{array}$ & $\begin{array}{c}0.24 \\
(0.43)\end{array}$ & $\begin{array}{c}0.26 \\
(0.44)\end{array}$ & $\begin{array}{c}0.22 \\
(0.41)\end{array}$ \\
\hline$N$ & 7228 & 6796 & 2452 & 2817 \\
\hline
\end{tabular}

Notes: Only permanent workers and firms below 35 workers are included. The pre-reform period goes from 1986 to 1990, the post-reform period from 1991 to 1995. Standard deviations in parenthesis. 
Table 3: Firms. Descriptive statistics by firm size, before and after the reform

\begin{tabular}{lcccc}
\hline \hline Variables & Pre-reform & Post-reform & Pre-reform & Post-reform \\
& \multicolumn{2}{c}{ Small firms } & \multicolumn{2}{c}{ Large firms } \\
& \multicolumn{2}{c}{0.028} & 0.027 \\
& 0.050 & 0.045 & 0.028 & $(0.163)$ \\
Entry rate & $(0.218)$ & $(0.206)$ & $(0.166)$ & 0.029 \\
& 0.048 & 0.052 & 0.025 & $(0.168)$ \\
Exit rate & $(0.213)$ & $(0.221)$ & $(0.157)$ & 24.129 \\
& 6.073 & 6.475 & 25.027 & $(5.861)$ \\
Yearly average size of the firm & $(3.923)$ & $(4.141)$ & $(5.662)$ & 8695 \\
& 22207 & 22226 & 6921 & 0.095 \\
$N$ & 0.137 & 0.127 & 0.025 & $(0.123)$ \\
Variance of employment growth & $(0.096)$ & $(0.087)$ & $(.0153)$ & 49 \\
$N$ & 50 & 50 & 49 & \\
\hline \hline
\end{tabular}

Notes: Only firms below 35 workers are included. The pre-reform period goes from 1986 to 1990, the post-reform period from 1991 to 1995 . Standard deviations in parenthesis. 
Table 4: Effects of the 1990 reform on accessions by gender

Regressors

(1)

(2)

(3)

(4)

(5)

(6)

A. $\mathrm{MEN}-N=35762$

Post 1990

\begin{tabular}{cccccc}
\multicolumn{7}{c}{ A. MEN - N = 35762 } \\
0.014 & 0.001 & 0.002 & -0.001 & -0.007 & 0.002 \\
$(0.017)$ & $(0.012)$ & $(0.016)$ & $(0.017)$ & $(0.018)$ & $(0.023)$ \\
-0.023 & -0.025 & -0.025 & -0.025 & -0.039 & -0.068 \\
$(0.011)$ & $(0.012)$ & $(0.012)$ & $(0.012)$ & $(0.015)^{*}$ & $(0.02)^{* *}$ \\
-0.019 & -0.018 & -0.018 & -0.012 & -0.01 & 0.047 \\
$(0.001)^{* * *}$ & $(0.002)^{* * *}$ & $(0.002)^{* * *}$ & $(0.002)^{* *}$ & $(0.004)^{*}$ & $(0.006)^{* * *}$ \\
- & - & - & - & - & -0.336 \\
- & - & - & - & - & $(0.01)^{* * *}$
\end{tabular}

\begin{tabular}{cccccc}
\multicolumn{7}{c}{ A. MEN - N = 35762 } \\
0.014 & 0.001 & 0.002 & -0.001 & -0.007 & 0.002 \\
$(0.017)$ & $(0.012)$ & $(0.016)$ & $(0.017)$ & $(0.018)$ & $(0.023)$ \\
-0.023 & -0.025 & -0.025 & -0.025 & -0.039 & -0.068 \\
$(0.011)$ & $(0.012)$ & $(0.012)$ & $(0.012)$ & $(0.015)^{*}$ & $(0.02)^{* *}$ \\
-0.019 & -0.018 & -0.018 & -0.012 & -0.01 & 0.047 \\
$(0.001)^{* * *}$ & $(0.002)^{* * *}$ & $(0.002)^{* * *}$ & $(0.002)^{* *}$ & $(0.004)^{*}$ & $(0.006)^{* * *}$ \\
- & - & - & - & - & -0.336 \\
- & - & - & - & - & $(0.01)^{* * *}$
\end{tabular}

Post $1990 \times$ Small firms

Post $1990 \times$ Small firms $\times$ Pre-reform variance of empl. growth by sector

B. WOMEN $-N=19276$

\begin{tabular}{lcccccc} 
Post 1990 & 0.033 & -0.011 & -0.011 & -0.008 & -0.016 & 0.027 \\
& $(0.02)$ & $(0.007)$ & $(0.01)$ & $(0.011)$ & $(0.014)$ & $(0.021)$ \\
Small firms & 0.043 & 0.043 & 0.043 & 0.043 & 0.053 & 0.07 \\
& $(0.036)$ & $(0.035)$ & $(0.035)$ & $(0.035)$ & $(0.037)$ & $(0.028)^{*}$ \\
Post $1990 \times$ Small firms & -0.02 & -0.02 & -0.02 & -0.027 & -0.026 & 0.07 \\
Post $1990 \times$ Small firms $\times$ Pre-reform & $(0.002)^{* * *}$ & $(0.004)^{* *}$ & $(0.004)^{* *}$ & $(0.004)^{* * *}$ & $(0.007)^{* *}$ & $(0.002)^{* * *}$ \\
variance of empl. growth by sector & - & - & - & - & - & -0.515 \\
& & - & - & - & - & $(0.016)^{* * *}$ \\
Sector and Region fixed effects & YES & YES & YES & YES & YES & YES \\
Trend & YES & NO & NO & NO & NO & YES \\
Sector specific trends & NO & YES & YES & YES & YES & NO \\
Productivity & NO & NO & YES & YES & YES & NO \\
Recession dummy & NO & NO & NO & YES & NO & NO \\
GDP growth rate & NO & NO & NO & NO & YES & NO \\
\hline \hline
\end{tabular}

Notes: Only permanent workers and firms below 35 workers are included. Robust standard errors in parenthesis allow for clustering by period/size. All specifications control for sectoral and region effects, age, occupation and total number of employees in the firm. Some specifications include sectoral productivity which is calculated as value-added deflated using a sector-level PPI over the number of workers using 1995 as the base year. Columns (4), and (5) control for size-specific cyclical effects. Column (4) interacts the small dummy with an expansion dummy, which takes the value of 1 for 1992-1993 and 0 otherwise, while column (5) interacts the small dummy with GDP growth. Column (6) includes interactions between the small firm dummy, the post reform dummy and the pre-reform variance of employment growth by sector and size. *** denotes significance at the $1 \%$ level, $* *$ denotes significance at the $5 \%$ level and $*$ denotes significance at the $10 \%$ level. 
Table 5: Effects of the 1990 reform on separations by gender

\begin{tabular}{lllllll}
\hline \hline Regressors & $(1)$ & $(2)$ & (3) & (4) & (5)
\end{tabular}

\begin{tabular}{|c|c|c|c|c|c|c|}
\hline \multirow[b]{2}{*}{ Post 1990} & \multicolumn{6}{|c|}{ A. $\mathrm{MEN}-N=35762$} \\
\hline & $\begin{array}{l}-0.024 \\
(0.016)\end{array}$ & $\begin{array}{c}-0.045 \\
(0.011)^{* *}\end{array}$ & $\begin{array}{c}-0.045 \\
(0.011)^{* *}\end{array}$ & $\begin{array}{c}-0.039 \\
(0.01)^{* *}\end{array}$ & $\begin{array}{c}-0.03 \\
(0.008)^{* *}\end{array}$ & $\begin{array}{c}-0.037 \\
(0.012)^{* *}\end{array}$ \\
\hline Small firms & $\begin{array}{l}-0.015 \\
(0.024)\end{array}$ & $\begin{array}{l}-0.014 \\
(0.025)\end{array}$ & $\begin{array}{l}-0.014 \\
(0.025)\end{array}$ & $\begin{array}{l}-0.014 \\
(0.024)\end{array}$ & $\begin{array}{l}-0.014 \\
(0.024)\end{array}$ & $\begin{array}{c}-0.02 \\
(0.023)\end{array}$ \\
\hline Post $1990 \times$ Small firms & $\begin{array}{c}-0.029 \\
(0.001)^{* * *}\end{array}$ & $\begin{array}{c}-0.031 \\
(0.002)^{* * *}\end{array}$ & $\begin{array}{c}-0.031 \\
(0.002)^{* * *}\end{array}$ & $\begin{array}{c}-0.026 \\
(0.002)^{* * *}\end{array}$ & $\begin{array}{c}-0.031 \\
(0.002)^{* * *}\end{array}$ & $\begin{array}{c}-0.021 \\
(0.002)^{* * *}\end{array}$ \\
\hline $\begin{array}{l}\text { Post } 1990 \times \text { Small firms } \times \text { Pre-reform } \\
\text { variance of empl. growth by sector }\end{array}$ & - & - & - & - & - & $\begin{array}{l}0.028 \\
(0.017)\end{array}$ \\
\hline & \multicolumn{6}{|c|}{ B. WOMEN - $N=19276$} \\
\hline Post 1990 & $\begin{array}{c}0.037 \\
(0.015)^{*}\end{array}$ & $\begin{array}{c}-0.032 \\
(0.008)^{* *}\end{array}$ & $\begin{array}{l}-0.018 \\
(0.012)\end{array}$ & $\begin{array}{l}-0.021 \\
(0.012)\end{array}$ & $\begin{array}{l}-0.012 \\
(0.013)\end{array}$ & $\begin{array}{c}0.035 \\
(0.015)\end{array}$ \\
\hline Small firms & $\begin{array}{c}0.034 \\
(0.017)\end{array}$ & $\begin{array}{c}0.034 \\
(0.017)\end{array}$ & $\begin{array}{c}0.033 \\
(0.017)\end{array}$ & $\begin{array}{c}0.033 \\
(0.017)\end{array}$ & $\begin{array}{c}0.059 \\
(0.017)^{* *}\end{array}$ & $\begin{array}{c}0.12 \\
(0.031)^{* *}\end{array}$ \\
\hline Post $1990 \times$ Small firms & $\begin{array}{c}-0.034 \\
(0.001)^{* * *}\end{array}$ & $\begin{array}{c}-0.035 \\
(0.003)^{* * *}\end{array}$ & $\begin{array}{c}-0.033 \\
(0.003)^{* * *}\end{array}$ & $\begin{array}{c}-0.04 \\
(0.004)^{* * *}\end{array}$ & $\begin{array}{c}-0.047 \\
(0.005)^{* * *}\end{array}$ & $\begin{array}{c}0.13 \\
(0.004)^{* * *}\end{array}$ \\
\hline $\begin{array}{l}\text { Post } 1990 \times \text { Small firms } \times \text { Pre-reform } \\
\text { variance of empl. growth by sector }\end{array}$ & - & - & - & - & - & $\begin{array}{c}-0.994 \\
(0.025)^{* * *}\end{array}$ \\
\hline Sector and Region fixed effects & YES & YES & YES & YES & YES & YES \\
\hline Trend & YES & NO & NO & NO & NO & YES \\
\hline Sector specific trends & NO & YES & YES & YES & YES & NO \\
\hline Productivity & NO & NO & YES & YES & YES & NO \\
\hline Recession dummy & NO & NO & NO & YES & NO & $\mathrm{NO}$ \\
\hline GDP growth rate & NO & NO & $\mathrm{NO}$ & NO & YES & NO \\
\hline
\end{tabular}

Notes: Only permanent workers and firms below 35 workers are included. Robust standard errors in parenthesis allow for clustering by period/size. All specifications control for sectoral and region effects, age, occupation and total number of employees in the firm. Some specifications include sectoral productivity which is calculated as value-added deflated using a sector-level PPI over the number of workers using 1995 as the base year. Columns (4), and (5) control for size-specific cyclical effects. Column (4) interacts the small dummy with an expansion dummy, which takes the value of 1 for 1992-1993 and 0 otherwise, while column (5) interacts the small dummy with GDP growth. Column (6) includes interactions between the small firm dummy, the post reform dummy and the pre-reform variance of employment growth by sector and size. ${ }^{* * *}$ denotes significance at the $1 \%$ level, $* *$ denotes significance at the $5 \%$ level and $*$ denotes significance at the $10 \%$ level. 
Table 6: Effects of the 1990 reform on firms' internal margin of adjustment

\begin{tabular}{lllllll}
\hline \hline Regressors & (1) & (2) & (3) & (4) & (5) & (6) \\
\hline
\end{tabular}

DEPENDENT VARIABLE: Absolute value of the growth rate of emplyoment $-N=41586$

\begin{tabular}{lcccccc} 
Post 1990 & 0.05 & 0.056 & 0.05 & 0.025 & 0.017 & 0.018 \\
& $(0.002)^{* * *}$ & $(0.002)^{* * *}$ & $(0.002)^{* * *}$ & $(0.01)$ & $(0.011)$ & $(0.011)$ \\
Small firms & 0.166 & 0.169 & 0.169 & 0.075 & 0.075 & 0.07 \\
& $(0.026)^{* * *}$ & $(0.025)^{* * *}$ & $(0.025)^{* * *}$ & $(0.015)^{* * *}$ & $(0.015)^{* * *}$ & $(0.018)^{* * *}$ \\
Post $1990 \times$ Small firms & -0.051 & -0.057 & -0.057 & -0.032 & -0.032 & -0.029 \\
& $(0.002)^{* * *}$ & $(0.002)^{* * *}$ & $(0.003)^{* * *}$ & $(0.01)^{* * *}$ & $(0.011)^{* * *}$ & $(0.011)^{* * *}$ \\
Sector and Region fixed effects & & & & & & \\
Trend & YES & YES & YES & YES & YES & YES \\
Sector specific trends & YES & NO & NO & NO & NO & NO \\
Productivity & NO & YES & YES & YES & YES & YES \\
Recession dummy & NO & NO & YES & YES & YES & YES \\
GDP growth rate & NO & NO & NO & NO & YES & NO \\
Firms fixed effects & NO & NO & NO & NO & NO & YES \\
\hline \hline
\end{tabular}

Notes: Only firms below 35 workers are included. In panel A robust standard errors in parenthesis allow for clustering by period/size. When possible, observations are weighted for the probability that a firms actually enters the sample (given by the average number of employees/90). All specifications control for fixed sectoral and region effects and for the total number of employees in the firm. Some specifications include sectoral productivity which is calculated as value-added deflated using a sector-level PPI over the number of workers using 1995 as the base year. Columns (5), and (6) control for size-specific cyclical effects. Column (5) interacts the small dummy with an expansion dummy, which takes the value of 1 for 1992-1993 and 0 otherwise, while columns (6) interacts the small dummy with GDP growth. *** Denotes significance at the 1\% level, $* *$ denotes significance at the $5 \%$ level and * denotes significance at the $10 \%$ level. 
Table 7: Effects of the 1990 reform on firms' entry and exit

\begin{tabular}{|c|c|c|c|c|c|c|c|c|}
\hline Regressors & (1) & (2) & (3) & (4) & (5) & (6) & (7) & (8) \\
\hline & \multicolumn{8}{|c|}{ A. DEPENDENT VARIABLE: ENTRY DUMMY - $N=60562$} \\
\hline Post 1990 & $\begin{array}{c}0.008 \\
(0.008)\end{array}$ & $\begin{array}{c}0.009 \\
(0.007)\end{array}$ & $\begin{array}{c}0.01 \\
(0.008)\end{array}$ & $\begin{array}{c}0.019 \\
(0.005)^{* * *}\end{array}$ & $\begin{array}{c}0.014 \\
(0.005)^{* * *}\end{array}$ & $\begin{array}{c}0.01 \\
(0.005)^{* *}\end{array}$ & $\begin{array}{l}0.004 \\
(0.01)\end{array}$ & $\begin{array}{c}0.007 \\
(0.007)\end{array}$ \\
\hline Small firms & $\begin{array}{l}-0.066 \\
(0.023)^{*}\end{array}$ & $\begin{array}{l}-0.066 \\
(0.023)^{*}\end{array}$ & $\begin{array}{c}-0.066 \\
(0.023)^{*}\end{array}$ & $\begin{array}{l}-0.001 \\
(0.007)\end{array}$ & $\begin{array}{l}-0.002 \\
(0.007)\end{array}$ & $\begin{array}{c}0.003 \\
(0.009)\end{array}$ & $\begin{array}{c}-0.113 \\
(0.021)^{* *}\end{array}$ & $\begin{array}{l}-0.019 \\
(0.033)\end{array}$ \\
\hline Post $1990 \times$ Small firms & $\begin{array}{c}-0.005 \\
(0.001)^{* *}\end{array}$ & $\begin{array}{c}-0.005 \\
(0.001)^{* *}\end{array}$ & $\begin{array}{c}-0.005 \\
(0.001)^{* *}\end{array}$ & $\begin{array}{l}-0.009 \\
(0.005)^{*}\end{array}$ & $\begin{array}{l}-0.009 \\
(0.005)^{*}\end{array}$ & $\begin{array}{c}-0.012 \\
(0.006)^{* *}\end{array}$ & $\begin{array}{c}0.035 \\
(0.004)^{* * *}\end{array}$ & $\begin{array}{c}0.026 \\
(0.019)\end{array}$ \\
\hline $\begin{array}{l}\text { Post } 1990 \times \text { Small firms } \times \text { Pre-reform } \\
\text { variance of empl. growth by sector }\end{array}$ & $\begin{array}{l}- \\
-\end{array}$ & - & - & - & - & - & $\begin{array}{c}-0.218 \\
(0.009)^{* * *}\end{array}$ & $\begin{array}{l}-0.216 \\
(0.113)^{*}\end{array}$ \\
\hline
\end{tabular}

\section{B. DEPENDENT VARIABLE: EXIT DUMMY - $N=60562$}

\begin{tabular}{|c|c|c|c|c|c|c|c|c|}
\hline Post 1990 & $\begin{array}{c}0.007 \\
(0.001)^{* * *}\end{array}$ & $\begin{array}{c}0.008 \\
(0.002)^{* *}\end{array}$ & $\begin{array}{c}0.008 \\
(0.002)^{* *}\end{array}$ & $\begin{array}{c}-0.03 \\
(0.005)^{* * *}\end{array}$ & $\begin{array}{c}-0.032 \\
(0.005)^{* * *}\end{array}$ & $\begin{array}{c}-0.031 \\
(0.006)^{* * *}\end{array}$ & $\begin{array}{l}-0.001 \\
(0.001)\end{array}$ & $\begin{array}{c}-0.031 \\
(0.007)^{* * *}\end{array}$ \\
\hline Small firms & $\begin{array}{c}-0.11 \\
(0.024)^{* *}\end{array}$ & $\begin{array}{c}-0.109 \\
(0.024)^{* *}\end{array}$ & $\begin{array}{c}-0.109 \\
(0.024)^{* *}\end{array}$ & $\begin{array}{c}-0.031 \\
(0.007) * * *\end{array}$ & $\begin{array}{c}-0.031 \\
(0.007)^{* * *}\end{array}$ & $\begin{array}{c}-0.029 \\
(0.009) * * *\end{array}$ & $\begin{array}{c}-0.138 \\
(0.024)^{* * *}\end{array}$ & $\begin{array}{c}0.049 \\
(0.034)\end{array}$ \\
\hline Post $1990 \times$ Small firms & $\begin{array}{c}0.011 \\
(0.001)^{* * *}\end{array}$ & $\begin{array}{c}0.009 \\
(0.002)^{* *}\end{array}$ & $\begin{array}{c}0.009 \\
(0.002)^{* *}\end{array}$ & $\begin{array}{c}0.028 \\
(0.005)^{* * *}\end{array}$ & $\begin{array}{c}0.026 \\
(0.005)^{* * *}\end{array}$ & $\begin{array}{c}0.027 \\
(0.006)^{* * *}\end{array}$ & $\begin{array}{c}-0.012 \\
(0.003)^{* *}\end{array}$ & $\begin{array}{l}0.015 \\
(0.02)\end{array}$ \\
\hline $\begin{array}{l}\text { Post } 1990 \times \text { Small firms } \times \text { Pre-reform } \\
\text { variance of empl. growth by sector }\end{array}$ & - & - & - & - & - & - & $\begin{array}{c}0.183 \\
(0.013)^{* * *}\end{array}$ & $\begin{array}{c}0.076 \\
(0.116)\end{array}$ \\
\hline Sector and Region fixed effects & YES & YES & YES & YES & YES & YES & YES & YES \\
\hline Trend & YES & NO & NO & NO & NO & NO & YES & NO \\
\hline Sector specific trends & NO & YES & YES & YES & YES & YES & NO & NO \\
\hline Productivity & NO & NO & YES & YES & YES & YES & NO & YES \\
\hline Recession dummy & NO & NO & NO & NO & YES & NO & NO & NO \\
\hline GDP growth rate & NO & NO & NO & $\mathrm{NO}$ & $\mathrm{NO}$ & YES & NO & YES \\
\hline Firms fixed effects & $\mathrm{NO}$ & $\mathrm{NO}$ & NO & YES & YES & YES & NO & YES \\
\hline
\end{tabular}

Notes: Only firms below 35 workers are included. Robust standard errors in parenthesis allow for clustering by period/size. When possible, observations are weighted for the probability that a firms actually enters the sample (given by the average number of employees/90). All specifications control for fixed sectoral and region effects and for the total number of employees in the firm. Some specifications include sectoral productivity which is calculated as value-added deflated using a sector-level PPI over the number of workers using 1995 as the base year. Columns (5), and (6) control for size-specific cyclical effects. Column (5) interacts the small dummy with an expansion dummy, which takes the value of 1 for 1992-1993 and 0 otherwise, while columns (6) interacts the small dummy with GDP growth. Columns (7) and (8) include interactions between the small firm dummy, the post reform dummy and the pre-reform variance of employment growth by sector and size. $* * *$ Denotes significance at the $1 \%$ level, $* *$ denotes significance at the $5 \%$ level and $*$ denotes significance at the $10 \%$ level. 